\title{
ВПЛИВ ЕКСПЛУАТАЦЙНИХ ФАКТОРІВ ТА КОНСТРУКТИВНИХ ПАРАМЕТРІВ МАЛОТОНАЖНИХ АВТОМОБІЛЬНИХ ПОЇЗДІВ НА МІЦНІСТЬ І НАДІЙНІСТЬ РАМ ОДНОВІСНИХ ПРИЧЕПІВ
}

\footnotetext{
Розвиток малого бізнесу і підприємництва в країні призвели до збільшення потреби в причепах, які використовуються разом з легковими автомобілями і автомобілями малої вантажопідйомності. Вказана обставина ставить завдання збільшення обсягів виробництва причіпної техніки даного виду, скорочення термінів проектування і початку виробництва нових моделей. Разом з цим несуча конструкція кожного виробу повинна володіти високою міцністю, довговічністю i забезпечувати безпечний рух малотонажного автомобільного поїзда в цілому.

Особливістю несучої конструкції одновісного причепа є наявність дишла, яке сприймає частину ваги причіпної ланки з вантажем, що перевозиться, і забезпечує зв'язок між автомобілем-тягачем і причепом. У зв'язку з цим, до дишла причепа висуваються високі вимоги по міцності і довговічності. Відмінність конструкції дишла одновісного причепа від рами транспортних машин великої вантажопідйомності не дозволяє використовувати традиційні методи і способи підвищення міцності і довговічності даного елемента, які неминуче призведуть до збільшення розмірів дишла, його маси і вартості виготовлення, що абсолютно неприпустимо в умовах масового виробництва.

Викладені вище обставини вказують на актуальність методів оптимізації масових, геометричних параметрів та пружних характеристик підвіски одновісних причепів під типові умови експлуатації малотоннажних автомобільних поїздів, що враховують особливості конструкції дишла.

Ключові слова: малотонажний автопоїзд, причіпна ланка, конструктивні параметри, несуча конструкція, дишло, навантажувальні режими, міцність, довговічність.
}

\section{ВСТУП}

Необхідні міцність і довговічність дишла можуть бути забезпечені шляхом оптимізації масових, геометричних параметрів та пружних характеристик підвіски одновісного причепа малої вантажопідйомності.

Істотний вплив на міцність і довговічність дишла надають навантажувальні режими, які визначаються рівністю дороги і швидкістю руху малотонажного автомобільного поїзда.

Накопичений досвід створення рам показує, що необхідні міцність і довговічність можуть бути досягнуті оптимізацією конструкції транспортної машини під типові умови експлуатації. Таким чином, рішення науково-технічної задачі створення високоміцної і довговічної несучої конструкції одновісних причепів неможливо без урахування типових експлуатаційних режимів малотоннажних автомобільних поїздів.

\section{АНАЛІЗ ЛІТЕРАТУРНИХ ДАНИХ ТА ПОСТАНОВКА ПРОБЛЕМИ}

Питанням дослідження міцності, довговічності і надійності несучих систем транспортних машин присвячені роботи багатьох вітчизняних і зарубіжних вчених: М.В. Аврамова, Т.В. Астахова, Альдайуб Зіяд, В.В. Болотіна, А.П. Бондаренко, І.Д. Галімянова, Б.В. Гольда, М.І. Горбацевич, Л.А. Жогова, В.Н. Зузова, А.А. Іванова, В.П. Когаева, В.А. Колокольцева, В.П. Копрових, Р.В. Кугеля, С.Ю. Лушнікова, В.К. Магомедова, В.П. Макєєва, А.П. Мельчакова, Ж.Ю. Моісеєнко, Л.М. Орлова, П.Д. Павленко, А.І. Панова, Ю.А. Полякова, В.А., В.В. Сафонова, Світлицького, С.В. Серенсена, К.Е. Сібгатулліна, А.Е. Січко, Ф.А. Фараджіева, В.С. Фільзенштейна, L.F. Coffina, S.S. Mansona, J. Morrow, H.J. Beermanna, D. Fucha, H. Oehlschlaeqera.

Дослідження надійності і міцності напівпричепів ТМЗ 879, показали, що 92,3\% напівпричепів мають втомні тріщини основи платформи, відмови рами через втомлювальні тріщини нечасті (3,5\%). Експериментально було встановлено, що найбільші за величиною напруження $\left(\sigma=315 \kappa \Gamma / \mathrm{cm}^{2}\right)$ виникали на ділянці дороги 3 обробленою поверхнею. Застосування додаткових опор в основі вантажної платформи дозволило зменшити величину напружень в небезпечному перерізі платформи в 1,6 рази і підвищити іiі ресурс з 38,95 тис. км до 122 тис. км.

При вирішенні проблеми підвищення надійності автомобільного поїзда в умовах гірської місцевості встановлено, що найменш надійними є зчіпний пристрій і зварні з'єднання рами напівпричепа. Напрацювання на відмову в цілому по напівпричепу нижче на 25,33\%, для деяких вузлів - на 10,45\%, в порівнянні з напівпричепом, експлуатація якого здійснюється в умовах рівнини. 
Експериментальні дослідження Горбацевич М.I. [17] показали наявність гармонійної складової навантаження деталей ходової частини тягача причіпного автомобільного поїзда, частота якої визначається типом дороги. Переважною в спектрі навантажень балки ведучого моста для асфальтобетонного покриття $є$ частота 2,5 Гц, для бруківки - 2,0 Гц. Спектральним аналізом встановлено, що для підресорених частин автомобіля характерні коливання частотою від 1,5 до 4,5 Гц, непідресорених частин - 7:10 Гц [17]. Узагальнюючи результати аналітичного i експериментального [17] досліджень, слід зробити висновок, що несуча конструкція будьтранспортної машини піддається навантаженням низької частоти.

Дослідження міцності рам причіпних ланок великої вантажопідйомності, як закритих просторових конструкцій, показали, що небезпечним навантажувальним режимом $є$ скручуючий момент, що виникає при русі через нерівності під кутом. Найбільш навантаженими елементами несучої конструкції причепа великої вантажопідйомності $\epsilon$ зчіпний шворінь $\mathrm{i}$ ділянка 3 кронштейнами підвіски.

Характерною несправністю рами одновісних причепів вантажних поїздів $є$ втомлювальна тріщина. Основною зоною локалізації тріщин $є$ дишло, на яке припадає 93\% їх загальної кількості. Поверхня тріщин має обриси розриву. Аналіз напруженого стану показав, що причиною виникнення тріщин є недостатня площа поперечного перерізу, форма якого не оптимальна і сприяє зниженню площі перетину.

Експериментальними дослідженнями міцності несучої системи одновісного причепа малої вантажопідйомності встановлено, що:

- закриті борти дозволяють на 20\% підвищити жорсткість несучої системи одновісного причепа;

- жорстка фіксація бортів в замкових пристроях істотно знижує рівень максимальних напружень в основі платформи до 40\%;

- небезпечним режимом руху причепа з точки зору виникнення максимальних напружень в поперечинах основи є рух на межі бокового ковзання коліс при максимальному значенні коефіцієнта зчеплення. Це призводить до зростання напружень в поперечинах основи в 1,5 ... 2 рази;

- застосування нероз'ємної установки крил бортів за допомогою зварювання незначною мірою зменшує величину напружень в панелях бортів (в межах 10\%).

Орлов Л.Н. [7] на основі результатів експерименту рекомендує: знизити металоємність конструкції причепа без втрати міцності заміною профілю стійок бортів, а також перетину $(60 \times 40)$ елементів основи платформи на менший закритий профіль 3 розміром $40 \times 28$. Довговічність важелів підвіски причепа може бути збільшена посиленням труби в місцях концентрації напружень $\mathrm{i}$ збільшенням діаметра осі коліс з боку стопорної втулки. Однак питання міцності і довговічності дишла одновісного причепа малої вантажопідйомності не висвітлені в його роботі [7].

Окремо слід відзначити роботи, спрямовані на дослідження навантажувальних режимів зчіпних пристроїв і трансмісій автомобільних поїздів, тому що вони визначають навантажувальні режими зчіпних шворнів, плит, петель і дишел. Результати дослідження показують, що попередня деформація пружного елемента зчіпного пристрою практично не впливає на навантажувальні режими зчіпного гака. Динамічні навантаження зчіпного пристрою визначаються жорсткістю пружного елемента і величиною зазору. Застосування беззазорного зчіпного пристрою дозволить знизити динамічні навантаження трансмісії тягача на 11-18\%.

Січко А.С. [14] показані причини зростання навантаженості трансмісії тягача при русі автомобільного поїзда, які пов'язані зі збільшенням величини власних частот трансмісії. Величину поздовжнього зусилля в зчіпному пристрої визначають крутний момент, що передається трансмісією, рівність дороги і швидкість руху автомобільного поїзда. Разом 3 тим вплив швидкості руху автомобільного поїзда на діапазон зусиль дещо менше.

На підставі проведеного аналізу можна зробити висновок, що:

- несуча система причіпної техніки сприймає низькочастотне навантаження. Дана обставина має бути врахована при оцінці міцності і довговічності несучої системи транспортної машини;

- основними причинами відмов причіпної техніки є втомні тріщини рам і вантажних платформ;

- найбільш навантаженими є зони розташування зчіпних шворнів, плит, зчіпних петель, дишел і лонжеронів в зоні розташування кронштейнів кріплення підвіски. Таким чином, при проведенні проектних розрахунків, необхідно в першу чергу звернути увагу на найбільш навантажені зони несучої системи причіпної ланки. Забезпечення міцності і довговічності дишел несучих систем причіпних ланок малотонажних автопоїздів $\epsilon$ важливим завданням підвищення безпеки руху 
автомобільного поїзда.

\section{ЦІЛЬ ТА ЗАДАЧІ ДОСЛІДЖЕННЯ}

Метою роботи є аналіз впливу експлуатаційних факторів та конструктивних параметрів, що впливають на міцність i довговічність несучих систем одновісних причепів малотонажних автопоїздів.

\section{РЕЗУЛЬТАТИ ДОСЛІДЖЕНЬ}

В процесі експлуатації одновісних причепів малої вантажопідйомності виникають руйнування і пластичні деформації елементів несучих систем (рисунок 1.1 - 1.6). Як показує досвід експлуатації, основними місцями локалізації тріщин є лонжерони, поперечини, дишло і деталі підвісок. Небезпечним перетином дишла $є$ зона кріплення до рами причепа, в якій зафіксовано часте виникнення тріщин.

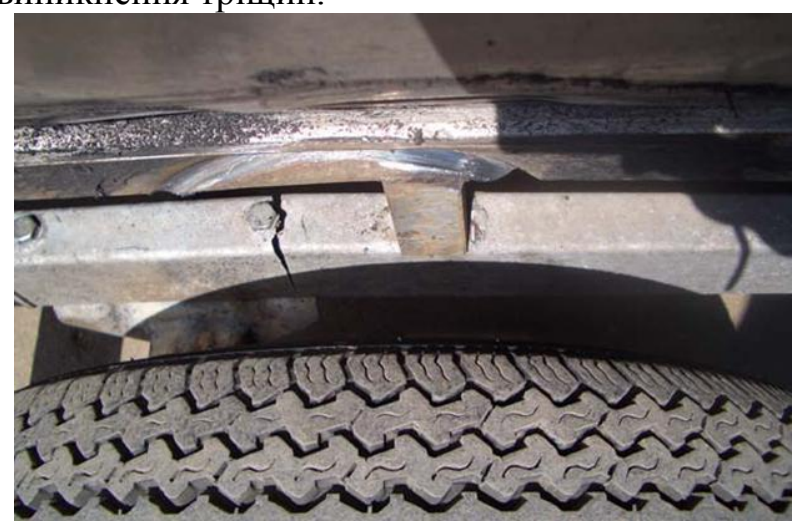

Рисунок 1.1 - Руйнування лонжерона рами одновісного причепа

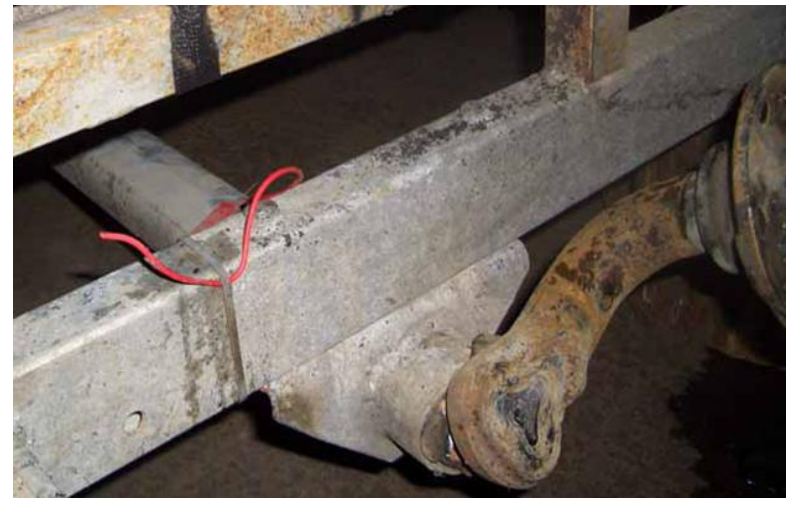

Рисунок 1.3 - Руйнування поздовжнього важеля підвіски одновісного причепа

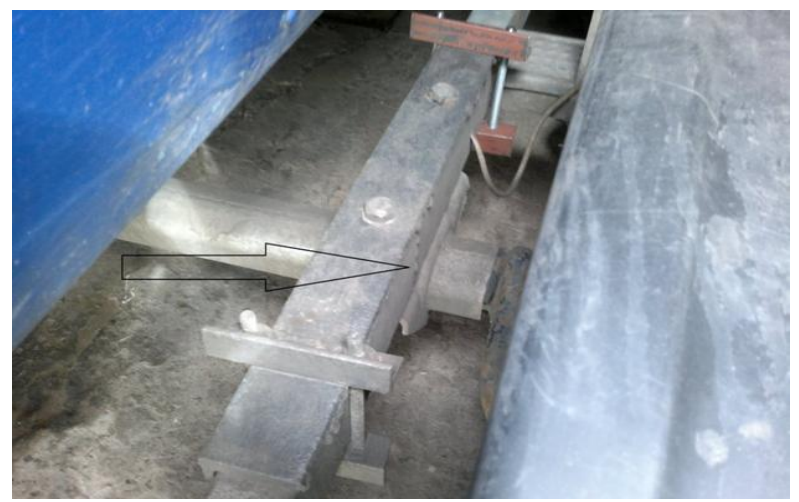

Рисунок 1.5 -Посилення лонжерона рами одновісного причепа

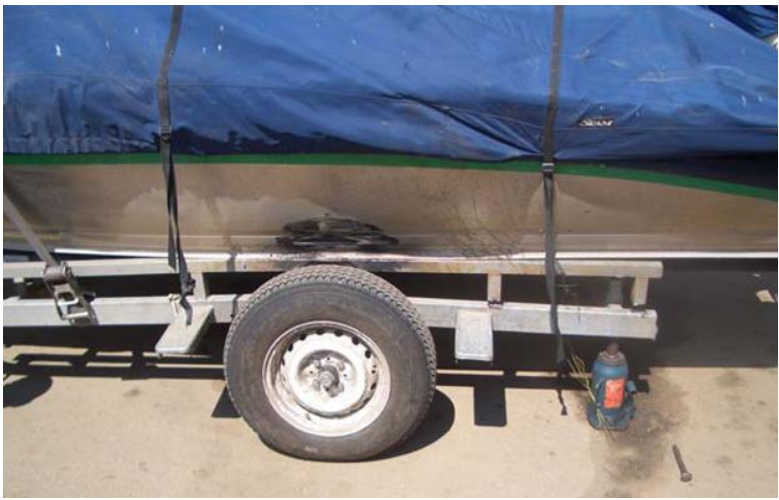

Рисунок 1.2 - Руйнування просторової рами одновісного причепа

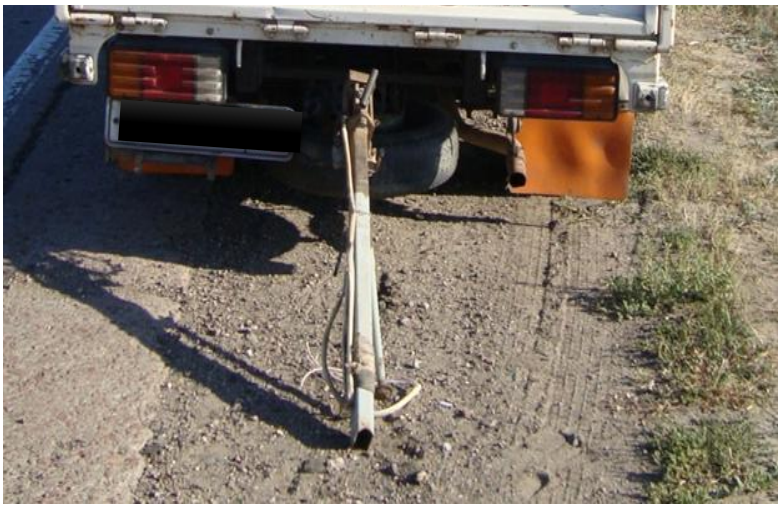

Рисунок 1.4 - Руйнування дишла одновісного причепа в зоні з'єднання з рамою

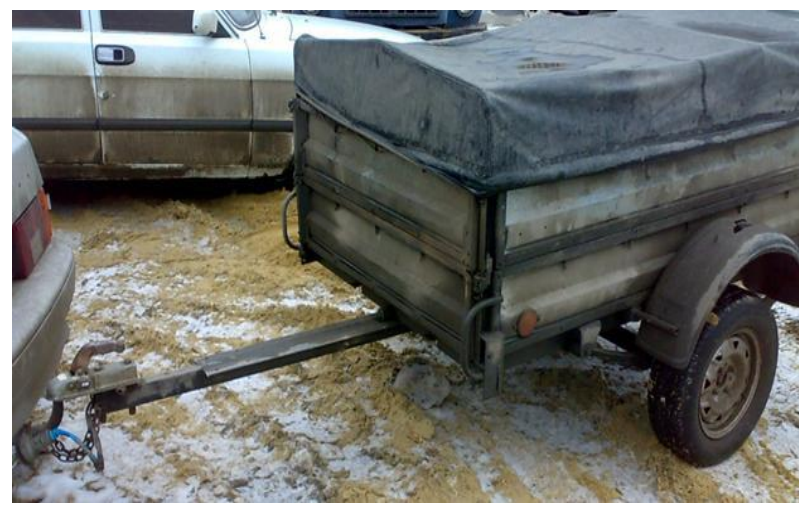

Рисунок 1.6 - Посилення дишла одновісного причепа

У загальному випадку оцінка втомлювальної міцності і довговічності рами транспортної машини проводиться в три етапи: на першому виконується розрахунок показників плавності ходу транспортної машини як абсолютно твердого тіла, на другому - аналіз напружено-деформованого 
стану з урахуванням пружних деформацій несучої системи транспортної машини, на третьому безпосередньо визначаються ресурс і довговічність рами.

У роботах деяких авторів [6] при аналізі плавності ходу транспортної машини використовувався імітаційний метод, що включає побудову n-масових динамічних моделей $\mathrm{i}$ проведення розрахункових експериментів. Рух транспортної машини і їі частин описується системою диференціальних рівнянь виду:

$$
[A] \cdot\{\ddot{U}\}+[B] \cdot\{\dot{U}\}+[C] \cdot\{U\}=\sum\{f\}_{i},
$$

де [A] - матриця інерційних коефіцієнтів;

[B] - матриця коефіцієнтів демпфірування;

[C] - матриця жорсткістних коефіцієнтів;

$\{\mathrm{U}\}$ - вектор-стовпець невідомих;

\{f\} - вектор-стовпець збурень від і-ого фактора.

Перевагою даного методу $є$ можливість дослідження будь-яких динамічних моделей без обмеження числа ступенів свободи.

Метод спектрального аналізу при дослідженні плавності ходу транспортної машини використовувався в роботі [4] та ін.. Суть методу полягає в поданні лінійної динамічної моделі машини системою автоматичного регулювання, для якої визначена амплітудно-частотна характеристика i, тим самим, встановлено зв'язок між входом коливальної системи і її виходом. У цьому випадку рух транспортної машини описується системою лінійних рівнянь (1.2):

$$
\left\{\begin{array}{l}
\left([C]-w^{2} \cdot[A]\right) \cdot\left\{U_{1}\right\}_{i}+w \cdot[B] \cdot\left\{U_{2}\right\}_{i}=\left\{f_{0}\right\}_{i} \\
-w \cdot[B] \cdot\left\{U_{1}\right\}_{i}+\left([C]-w^{2} \cdot[A]\right) \cdot\left\{U_{2}\right\}_{i}=0
\end{array},\right.
$$

де [A] - матриця інерційних коефіцієнтів;

[B] - матриця коефіцієнтів демпфірування;

[C] - матриця жорсткістних коефіцієнтів;

$\{\mathrm{U}\}$ - вектор-стовпець невідомих;

\{f\} - вектор-стовпець збурень від і-ого фактора.

У ряді робіт плавність ходу транспортних машин розглядалася з застосуванням детермінованих i стохастичних моделей поздовжнього профілю дороги. В роботі [9] при оцінці напруженодеформованого стану рами вантажного автомобіля визначалися кути крену підресорених мас при кососиметричних навантаженнях.

Розрахунок плавності ходу вантажного одновісного причепа при нерегулярному впливі автором [13] грунтується на припущенні абсолютно жорсткої і беззазорної зчіпки 3 автомобілемтягачем. Дане припущення не відповідає дійсності, оскільки дослідженнями [14] показано, що в зчіпному пристрої типу «гак-петля» нових автомобілів вже присутній зазор 10-12мм. В процесі експлуатації його величина має тенденцію тільки до збільшення і може досягати 25-40 мм [14]. Ця обставина робить негативний вплив на плавність ходу автомобільного поїзда, навантаженість деталей його ходової частини і несучої системи. Отже, наявність зазору в зчіпному пристрої повинно бути враховано при оцінці плавності ходу.

Математична модель зчіпного пристрою типу «гак-петля», що враховує зазор, запропонована в роботі [16]. Вирішуючи аналітично систему (1.1) відносно виникнувшої в процесі руху автомобільного поїзда деформації $\mathrm{S}$ пружного елемента, Щукіним М.М. отримана залежність (1.3) поздовжньої сили в зчіпному гаку $\mathrm{P}_{\Gamma}$ від компонувальних і масових параметрів ланок і характеристик зчіпного пристрою.

$$
P_{2}=P \cdot\left[1+\sqrt{1+\left(\frac{c \cdot V_{0 \varepsilon}}{P \cdot \beta}\right)} \cdot \sin (\beta \cdot t+\varepsilon)\right],
$$


де $\quad P=\left[m \cdot P_{a}-(1-m) \cdot P_{n}+m \cdot B \cdot\left(P_{a}+P_{n}\right)+B \cdot m \cdot f \cdot\left(G_{a}+G_{n}\right)\right] \cdot\left(\frac{1}{1-D}\right) \cdot$ с $\quad-\quad$ коефіцієнт

жорсткості пружного елемента зчіпного пристрою;

$\varepsilon$ - вихідна фаза навантаження;

$\beta$ - кутова частота власних відносних коливань ланок автомобільного поїзда;

$\mathrm{V}_{0 \varepsilon}$ - відносна швидкість ланок автомобільного поїзда до моменту вибору зазору в зчіпному пристрої автомобільного поїзда.

Автор [16] при побудові математичної моделі обмежується лише лінійною характеристикою пружного елемента зчіпного пристрою типу «гак-петля». Однак, експериментальні дані показують, що попереднє стиснення пружного елемента призводить до суттєвої нелінійності характеристики зчіпного пристрою, яка повинна бути врахована при проведенні розрахунків.

Моделюванню роботи зчіпного пристрою з урахуванням зазору і попереднього стиснення пружного елемента при спектральному аналізі плавності ходу i навантаженості деталей автомобільних поїздів присвячено працю [14]. Січко А.Є. [14] визначена передавальна функція крутного моменту трансмісії автомобіля-тягача від динамічного впливу на причіп методом статистичної лінеаризації нелінійності. Вихідна функція зчіпного пристрою з урахуванням зазору i стиснення пружного елемента дорівнює:

$$
\begin{gathered}
f(y)=K_{0} \cdot m_{x}+K_{01} \cdot X^{c}, \\
K_{01}=\operatorname{tg} \alpha \cdot\left[1-2 \cdot \Phi \cdot\left(\frac{\varepsilon}{\sqrt{D_{x}}}\right)\right]+\frac{2 \cdot P_{0}}{\sqrt{2 \cdot \pi \cdot D_{x}}} \cdot \exp \left\{-\frac{\varepsilon^{2}}{2 \cdot D_{x}}\right\}^{c},
\end{gathered}
$$

де $\mathrm{K}_{0}$ - статистичний коефіцієнт посилення по математичному очікуванню $\mathrm{mx}$;

$\mathrm{X}^{C}$ - центрована випадкова складова вхідного процесу;

$\alpha$ - кут нахилу пружно] характеристики тягово-зчіпного пристрою;

$\Phi(\cdot)$ - інтеграл ймовірності;

$\varepsilon$ - половина зазору тягово-зчіпного пристрою;

$\mathrm{D}_{\mathrm{x}}$ - дисперсія тягового пристрою;

$\mathrm{P}_{0}$ - зусилля попереднього стиснення тягово-зчіпного пристрою;

$\mathrm{K}_{01}$ - статичний коефіцієнт посилення по випадковій складовій.

Слід зазначити, що автором [14] враховувалися тільки вертикальні коливання підресорених i непідресорених частин автомобільного поїзда.

Дослідженнями $[2,12]$ встановлено, що нерівності дороги збуджують не тільки вертикальні коливання, але і горизонтальні. Таким чином, використання моделі [14] при проведенні аналізу плавності ходу і розрахунків на міцність обмежена.

Міцність і довговічність несучої системи транспортної машини визначається внутрішніми силовими факторами, що виникають в матеріалі елементів. На стадії проектування виникає необхідність в отриманні детальної інформації про напружено-деформований стан. Тому після визначення зовнішніх сил визначаються внутрішні силові фактори, методи розрахунку яких вибираються дослідниками в залежності від типу розв'язуваної задачі.

Проскуряков В.Б. [9] розрахунок на міцність лонжеронів рами, навантаженої згинальним моментом, пропонує вести методом початкових параметрів. Зусилля, що передаються від підвісок, $\epsilon$ зосередженими силами, вага рами і надбудови - розподіленим навантаженням. Згин рами описувався диференціальним рівнянням четвертого порядку, аналітичне рішення якого отримано у вигляді системи рівнянь: 


$$
\begin{aligned}
& f_{y}(z)=f_{y}(0)+f_{y}^{\prime}(0) z-\frac{M_{x}(0)}{2 E J_{x}} \cdot z^{2}-\frac{Q_{y}(0)}{6 E J_{x}} \cdot z^{3}-\frac{M_{x}(0)}{2 E J_{x}} \cdot(z-t)^{2}-\frac{Q_{y}(0)}{6 E J_{x}} \cdot(z-t)^{3} \\
& f_{y}^{\prime}(z)=f_{y}^{\prime}(0)-\frac{M_{x}(0)}{E J_{x}} \cdot z-\frac{Q_{y}(0)}{2 E J_{x}} \cdot z^{2}-\frac{M_{x}(t)}{E J_{x}} \cdot(z-t)-\frac{Q_{y}(t)}{2 E J_{x}} \cdot(z-t)^{2} \\
& M_{x}(z)=M_{x}(0)+Q_{y}(0) \cdot z+M_{x}(t)+Q_{y}(t) \cdot(z-t) \\
& Q_{y}(z)=Q_{y}(0)+Q_{y}(t)
\end{aligned}
$$

де $\mathrm{M}_{\mathrm{x}}$ - згинальний момент;

$\mathrm{Q}_{\mathrm{y}}$ - діюче зусилля;

Е - модуль пружності матеріалу;

x - момент інерції поперечного перерізу відносно осі ох;

$\mathrm{f}_{\mathrm{y}}$ - прогин несучого елемента у напрямку осі оу;

$\mathrm{z}, \mathrm{t}$ - координати перерізу несучого елемента.

Даний підхід дозволив автору визначити для рами вантажного автомобіля Урал-375 найбільш важкий режим навантаження і небезпечний переріз лонжеронів. При цьому місцеві ефекти від зміни висоти лонжеронів, з'єднань лонжеронів і поперечин (вузлів) не враховувалися. Між тим дослідження показали, що довговічність рами і корпусу транспортної машини лімітується міцністю вузлових зон, а саме міцністю з'єднання лонжеронів 3 поперечиною. Тому при проектуванні несучої системи транспортної машини розрахунки, виконані за методикою [9], є недостатніми і повинні бути доповнені оцінкою напружено-деформованого стану вузлових зон.

Задовільні результати при аналізі напружено-деформованого стану можна отримати за допомогою кінцево-елементної розрахункової схеми, що складається 3 пружних пластинок. Дана методика дозволяє досліджувати тіла складної геометричної форми 3 нерегулярними граничними умовами. Однак, виникає необхідність проведення великої кількості обчислень, що робить метод кінцевих елементів малопридатним на початкових стадіях проектування, коли потрібно виконати структурний і параметричний аналіз конструкції несучої системи.

В даний час набув активного розвитку метод скінченних елементів для аналізу напруженодеформованого стану на початкових стадіях проектування. Дослідники рекомендують при аналізі конструкції використовувати моделі з малим числом кінцевих елементів без істотної втрати точності розрахунків. Деякі автори вважають доцільними досліджувати напружено-деформований стан рами змішаними схемами, в яких несучий елемент між вузлами моделюється однорідним тонкостінним стрижнем, вузол - тонкостінними пластинками.

Аналіз розглянутих методик розрахунку внутрішніх силових факторів дозволяє зробити висновок про те, що на початкових етапах проектування при дослідженні загального напруженого i деформованого стану можна використовувати стрижневі моделі несучих систем, на завершальних етапах необхідно застосовувати метод кінцевих елементів.

Зовнішні силові фактори в вертикальній площині визначалися для випадку резонансу, поздовжнє зусилля - для нечистого удару. Розподіл внутрішніх силових факторів дишла і лонжеронів рами досліджувалися 3 допомогою плоскої моделі. Навантаження лонжеронів рами скручуючими моментами, що передаються від поперечок, не враховувалось. Напруження в довільному поперечному перерізі дишла розраховувалися:

$$
\sigma= \pm \frac{M_{32}}{W} \pm \frac{A}{F}
$$

де $\mathrm{M}_{3 г}$ - згинальний момент;

А - зусилля розтягу;

W - момент опору січення;

F - площа поперечного січення.

Проте запропонована методика має ряд недоліків. По-перше, при математичному моделюванні руху автомобільного поїзда наявність пружного елемента враховується тільки динамічним коефіцієнтом для нечистого удару, пружна характеристика зчіпного пристрою і коливальний

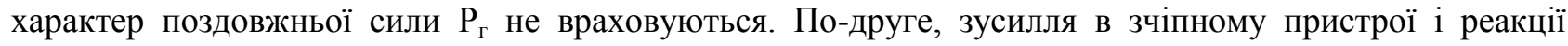
опорної поверхні носять екстремальних характер. Такий підхід дозволяє оцінити міцність дишла в 
разі одиничних імпульсних навантажень, що призводять до динамічного руйнування, i не дозволяє провести оцінку втомлювальної міцності. Методика розрахунку дишла одновісного причепа легкового автомобіля на міцність встановлена ДСТУ ISO 7641-1-93 [3]. Відповідно до стандарту, конструкція дишла одновісного причепа до легкового автомобіля вважається міцною, якщо виконується така умова:

$$
\sigma_{\text {розр }} \leq\left[\sigma_{\text {доn }}\right]=\min \left\{\begin{array}{l}
0,6 \sigma_{\beta} \\
0,8 \sigma_{T}
\end{array},\right.
$$

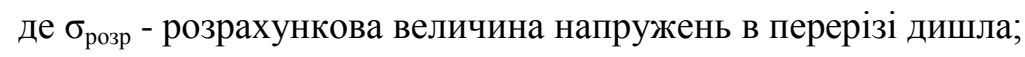

$\sigma_{\text {доп }}-$ гранично допустима величина напружень;

$\sigma_{\mathrm{B}}$ - межа міцності;

$\sigma_{\mathrm{T}}$ - межа текучості.

Розрахунок лівої частини нерівності ведеться при дії на дишло максимального статичного згинального моменту Мзг, величина якого для причепа, не оснащеного інерційною гальмовою системою, і параметри дишла відповідають умові е $/ 1<0,15$, визначається виразом:

де $\mathrm{M}_{3 г}$ - згинальний момент;

$$
M_{32}=0,24 \cdot P \cdot g \cdot l_{x},
$$

Р - повна маса одновісного причепа;

$\mathrm{g}$ - прискорення вільного падіння;

$1_{x}$ - координата небезпечного поперечного перерізу дишла.

В основному методики спрямовані на вдосконалення якої-небудь однієї системи автомобіля і не враховують вплив обраних параметрів на інші показники експлуатаційних якостей автомобільної техніки.

При оптимізації параметрів інерційної гальмової системи одновісного причепа малотонажного автомобільного поїзда може використовуватись функція бажаності Харрінгтона, яка встановлює зв'язок між суб'єктивними оцінками дослідника і об'єктивними чисельними показниками. В якості математичних моделей, що описують залежність критеріїв оптимальності від експлуатаційних i конструктивних параметрів, використовуються рівняння регресії. Узагальнена функція бажаності визначається за допомогою середньогеометричного значення частинних функцій бажаності:

$$
D=\sqrt[n]{d_{1} \cdot d_{2} \cdot \ldots \cdot d_{n}}
$$

де D - узагальнена функція бажаності;

$\mathrm{d}_{1}, \mathrm{~d}_{2}, \ldots, \mathrm{d}_{\mathrm{n}}$ - частинні функції бажаності (шкали бажаності)

$d_{i}=\exp \left(-\exp \left(-y_{i}^{\prime}\right)\right)$;

$n$ - кількість частинних функцій бажаності;

$y_{i}^{\prime}=b_{0}+b_{1} \cdot y_{i}$ - перетворення оціночного показника.

Однак, даний підхід є спрямованим пошуком рішення оптимізаційної задачі, використання даного методу обмежене і малоефективне.

\section{ОБГОВОРЕННЯ РЕЗУЛЬТАТІВ ДОСЛІДЖЕНЬ}

У науковій практиці використовують безліч математичних моделей, що дозволяють з високою точністю виконувати оцінку впливу експлуатаційних факторів та конструктивних параметрів транспортних машин великої вантажопідйомності і напружено-деформованого стану їх несучих конструкцій. Однак, розроблені математичні моделі не придатні для дослідження експлуатаційних властивостей малотонажних автомобільних поїздів, так як не враховують характерних особливостей, до яких відносяться розташування точки зчіпки за межами бази автомобіля-тягача і розподіл частини маси причіпної ланки на автомобіль-тягач. Моделі МАП, що дозволяють досліджувати навантаження несучої конструкції причіпної ланки, на сучасному етапі науково-технічного прогресу відсутні. Це створює певні труднощі при оцінці втомної міцності конструкції причіпної техніки малої вантажопідйомності і вимагає якнайшвидшого їі наукового вирішення.

\section{ВИСНОВОК}

В даний час при проектуванні раціональних конструкцій транспортних машин поширення набули методи багатокритеріальної параметричної оптимізації. Даний тип завдань ефективно 
вирішується ітераційним алгоритмами, тобто зондуванням простору значень параметрів i визначенням для даних точок показників, які оцінюють оптимальність конструкції. Використання методів даного класу дозволяє вирішувати широкий спектр оптимізаційних задач, однак вимагає великої кількості обчислень і, відповідно, трудовитрат.

Порушення справного стану несучих систем транспортних машин відбувається через втомлювальне руйнування іiі елементів. Звідси випливає, що крім розрахунку на міцність несучої системи при одиничному імпульсному впливі слід виконувати аналіз напружено-деформованого стану в разі дії змінних навантажень. Це справедливо для несучих систем одновісних причепів.

\section{ПЕРЕЛІК ДЖЕРЕЛ ПОСИЛАННЯ}

1. Антонов Д.А. Теория устойчивости движения многоосных автомобилей. - М.: Машиностроение, 1978. - 216 с.

2. Балакина, Е.В. Система «колесо-подвеска» и устойчивость движения автомобиля в режиме торможения: Монография / Е.В. Балакина, А.А. Ревин, А.А. Юрчевский, Н.Г. Кузнецов. - ВолгГТУ. Волгоград, 2004. - $306 \mathrm{c.}$

3. Засоби транспортні дорожні. Каравани и легкі причепи. Розрахунок механічної міцності сталевого дишла: ДСТУ ISO 7641-1-93. - [чинний від 2009-02-16]. - Офіц. вид. - К. : Держстандарт України, 2009. - 9 с. - (Державний стандарт України).

4. Динамика длиннобазных автопоездов / В.М. Высоцкий [и др.]; под ред. В.М. Высоцкого. Мн.: изд-во «Наука и техника». - 1987. - 204 с.

5. Динамика системы дорога - шина - автомобиль - водитель : монография / А.А. Хачатуров [и др.]; под ред. А.А. Хачатурова. - М.: Машиностроение. - 1976. - 535 с.

6. Исследование влияние ровности дорожного покрытия на плавность хода и колебания автомобиля / В.Г. Герасименко, Т.В. Москаленко, А.Г. Доля, И.В. Грицук // Вестник Донецкого института автомобильного транспорта. - Донецк, 2009. - № 2. - С.10-13.

7. Орлов, Л.Н. Комплексная оценка безопасности и несущей способности кабин, кузовов автомобилей, автобусов: дис. докт. техн. наук / Л.Н. Орлов. - Нижний Новгород, 2001. - 406 с.

8. Петрушов, В.А. Сопротивление качению автомобилей и автопоездов / В.А. Петрушов, С.А. Шуклин, В.В. Московкин. - М.: Машиностроение, 1975. - 225 с.

9. Проскуряков, В.Б. Динамика и прочность рам и корпусов транспортных машин : монография / В.Б. Проскуряков, В.С. Прозоров. - Л.: «Машиностроение». - 1972. - 232 с.

10. Прочность и долговечность автомобиля : учеб. пособие / Б.В. Гольд [и др.]; под ред. Б.В. Гольда. - М.: Машиностроение. - 1974. - 328 с.

11. Ревин, С.А. Повышение тормозных свойств малотоннажных автопоездов с АБС: автореферат дис. канд. техн. наук / С.А. Ревин. - Волгоград, 2003. -20 с.

12. Ротенберг, Р.В. Подвеска автомобиля : монография / Р.В. Ротенберг. - изд. 3-е, перераб. и доп. - М.: Машиностроение. - 1972. - 392 с.

13. Светлицкий, В.А. Случайные колебания механических систем / В.А. Светлицкий, С.Д. Пономарев, Н.А. Алфутов, В.Л. Бидерман, В.П. Когаев, Н.Н. Малинин. - М.: «Машиностроение». - 1976. - 216 с.

14. Сичко, А.Е. Нагруженность трансмиссии и тягово-сцепного устройства автомобиля типа $4 \times 2$ при движении с прицепом: дис. канд. техн. наук / А.Е. Сичко. - Киев, 1987. -217 с.

15. Тарасик, В.П. Теория движения автомобиля : учеб. для вузов / В.П. Тарасик. - СПб.: БХВ-Петербург. - 2006. -478 с.

16. Щукин, М.М. Сцепные устройства автомобилей и тягачей. Конструкция, теория и расчет : монография / М.М. Щукин. - М.: МАШГИЗ, 1931. - 205 с.

17. Горбацевич, М.И. Обработка конструкции и прогнозирование усталостной долговечности несущих деталей ходовой части транспортных средств: дис. канд. техн. наук / М.И. Горбацевич. Мн., 1984. $-176 \mathrm{c}$.

18. Колісні транспортні засоби. Вимоги щодо безпечності технічного стану та методи контролювання: ДСТУ 3649:2010. - [Чинний від 2011-07-01]. - Офіц. вид. - К.: Держспоживстандарт України, 2011. - 28 с. - (Національний стандарт України).

\section{REFERENCES}

1. Antonov, D.A. (1978). Teoriya ustoychivosti dvizheniya mnogoosnykh avtomobiley [The theory of 
stability of motion of multi-axle vehicles]. Moscow: Mashinostroenie [in Russian].

2. Balakina, E.V., \& Revin, A.A., \& Yurchevsky, A.A., \& Kuznetsov, N.G. (2004). Sistema «kolesopodveska» i ustoychivost' dvizheniya avtomobilya v rezhime tormozheniya [The "wheel-suspension" system and the stability of the vehicle in the braking mode]. Volgograd: VolgSTU [in Russian].

3. Zasoby transportni dorozhni. Karavany y lehki prychepy. Rozrakhunok mekhanichnoyi mitsnosti stalevoho dyshla [Road vehicles. Caravans and light trailers. Calculation of mechanical strength of steel drawbar] (2009). DSTU ISO 7641-1-93 from $16^{\text {th }}$ February 2009. Kyiv: Derzhstandart Ukraine, [in Ukrainian].

4. Vysotsky, V.M. (1987). Dinamika dlinnobaznykh avtopoyezdov [Dynamics of long-wheelbase road trains]. Minsk: Publishing House "Science and Technology" [in Belarus].

5. Khachaturov, A.A. (1976). Dinamika sistemy doroga - shina - avtomobil' - voditel' [Dynamics of the road - tire - car - driver system]. Moscow: Mashinostroenie [in Russian].

6. Gerasimenko, V.G., \& Moskalenko, T.V., \& Dolya, A.G., \& Gritsuk, I.V. (2009). Issledovaniye vliyaniye rovnosti dorozhnogo pokrytiya na plavnost' khoda i kolebaniya avtomobilya [nvestigation of the influence of the flatness of the road surface on the smoothness and vibration of the car]. Vestnik Donetskoy akademii avtomobil'nogo transporta - Bulletin of the Donetsk Academy of Motor Transport, 2, 10-13 [in Ukrainian].

7. Orlov, L.N. (2001). Kompleksnaya otsenka bezopasnosti i nesushchey sposobnosti kabin, kuzovov avtomobiley, avtobusov [Comprehensive assessment of safety and bearing capacity of cabins, car bodies, buses]. Doctor's thesis. Nizhny Novgorod [in Russian].

8. Petrushov, V.A., \& Shuklin, S.A., \& Moskovkin, V.V. (1975). Soprotivleniye kacheniyu avtomobiley i avtopoyezdov [Rolling resistance of cars and road trains]. Moscow: Mashinostroenie [in Russian].

9. Proskuryakov, V. B., \& Prozorov, V.S. (1972). Dinamika i prochnost' ram i korpusov transportnykh mashin [Dynamics and strength of frames and bodies of transport machines]. Leningrad: Mashinostroenie [in Russian].

10. Gold, B.V. (1974). Prochnost' i dolgovechnost' avtomobilya [Strength and durability of the car]. Moscow: Mashinostroenie [in Russian].

11. Revin, S.A. (2003). Povysheniye tormoznykh svoystv malotonnazhnykh avtopoyezdov s ABS [Improving the braking properties of low-tonnage road trains with ABS]. Extended abstract of candidate's thesis. Volgograd [in Russian]. Russian].

12. Rothenberg, R.V. (1972). Podveska avtomobilya [Car suspension]. Moscow: Mashinostroenie [in

13. Svetlitsky, V.A., \& Ponomarev, S. D., \& Alfutov, N.A., \& Biderman, V.L., \& Kogaev V.P., \& Malinin, N.N. (1976). Sluchaynyye kolebaniya mekhanicheskikh sistem [Random vibrations of mechanical systems]. Moscow: Mashinostroenie [in Russian].

14. Sichko, A.E. Nagruzhennost' transmissii i tyagovo-stsepnogo ustroystva avtomobilya tipa $4 \times 2$ pri dvizhenii s pritsepom [Load of transmission and towing device of a $4 \times 2$ car when driving with a trailer]. Candidate's thesis. Kiev [in Ukrainian].

15. Tarasik, V.P. (2006). Teoriya dvizheniya avtomobilya [The theory of car movement]. St. Petersburg: BHV-Petersburg [in Russian].

16. Shchukin, M.M. (1931). Stsepnyye ustroystva avtomobiley i tyagachey. Konstruktsiya, teoriya i raschet [Coupling devices for cars and tractors. Design, theory and calculation]. Moscow: Mashgiz [in Russian].

17. Gorbatsevich, M.I. (1984). Obrabotka konstruktsii i prognozirovaniye ustalostnoy dolgovechnosti nesushchikh detaley khodovoy chasti transportnykh sredstv [Processing of the structure and prediction of the fatigue life of the load-bearing parts of the undercarriage of vehicles]. Candidate's thesis. Minsk [in Belarus].

18. Kolisni transportni zasoby. Vimogi schodo bezpechnostI tehnIchnogo stanu ta metodi kontrolyuvannya [Wheeled vehicles. Requirements for safety of technical condition and control methods] (2011). DSTU 3649:2010 from 01 ${ }^{\text {th }}$ July 2011. Kyiv: Derzhstandart Ukraine, [in Ukrainian].

\section{Handziuk, D. Handziuk The influence of operational factors and constructive parameters of low-weight trains on the strength and reliability of the frames uniaxial trailers}

The development of small business and entrepreneurship in the country has led to an increase in the need for trailers used in conjunction with cars and light-duty vehicles. This circumstance sets the task of increasing the production of trailers of this type, reducing the design time and start production of new models. At the same time the bearing design of each product has to possess high durability, durability and to provide safe movement of the low-tonnage automobile train as a whole. 
A feature of the supporting structure of a single-axle trailer is the presence of a drawbar, which receives part of the weight of the trailer link with the transported load, and provides a connection between the tractor and the trailer. In this regard, the drawbar of the trailer has high requirements for strength and durability. The difference in the design of the drawbar of a single-axle trailer from the frame of heavy-duty vehicles does not allow the use of traditional methods and ways to increase the strength and durability of this element, which will inevitably increase the size of the drawbar, its weight and cost, which is absolutely unacceptable in mass production.

The above circumstances indicate the relevance of methods for optimizing the mass, geometric parameters and elastic characteristics of the suspension of single-axle trailers under typical operating conditions of low-capacity road trains, taking into account the design features of the drawbar.

Keywords: low-tonnage road train, trailer link, design parameters, LOADING MODES, drawbar, loading modes, strength, durability.

ГАНДЗЮК Микола Олександрович, кандидат технічних наук, доцент кафедри автомобілів і транспортних технологій Луцького національного технічного університету, e-mail: Gandzyuk64.MG@gmail.com. http://orcid.org/0000-0002-3552-4256.

ГАНДЗЮК Дмитро Миколайович, магістр із спеціальності «Автомобілі і автомобільне господарство», аспірант Луцького національного технічного університету, e-mail: Gandzyukd@gmail.com.

Mykola HANDZIUK, Ph.D in Engeneering, associate professor of automobiles and transport technologies department, Lutsk National Technical University, e-mail: Gandzyuk64.MG@gmail.com. http://orcid.org/0000-0002-3552-4256.

Dmitriy HANDZIUK, Magistr of Transport, Postgraduate Student of Lutsk National Technical University, e-mail: Gandzyukd@gmail.com.

DOI 10.36910/automash.v1i16.506 